Provided for non-commercial research and education use. Not for reproduction, distribution or commercial use.

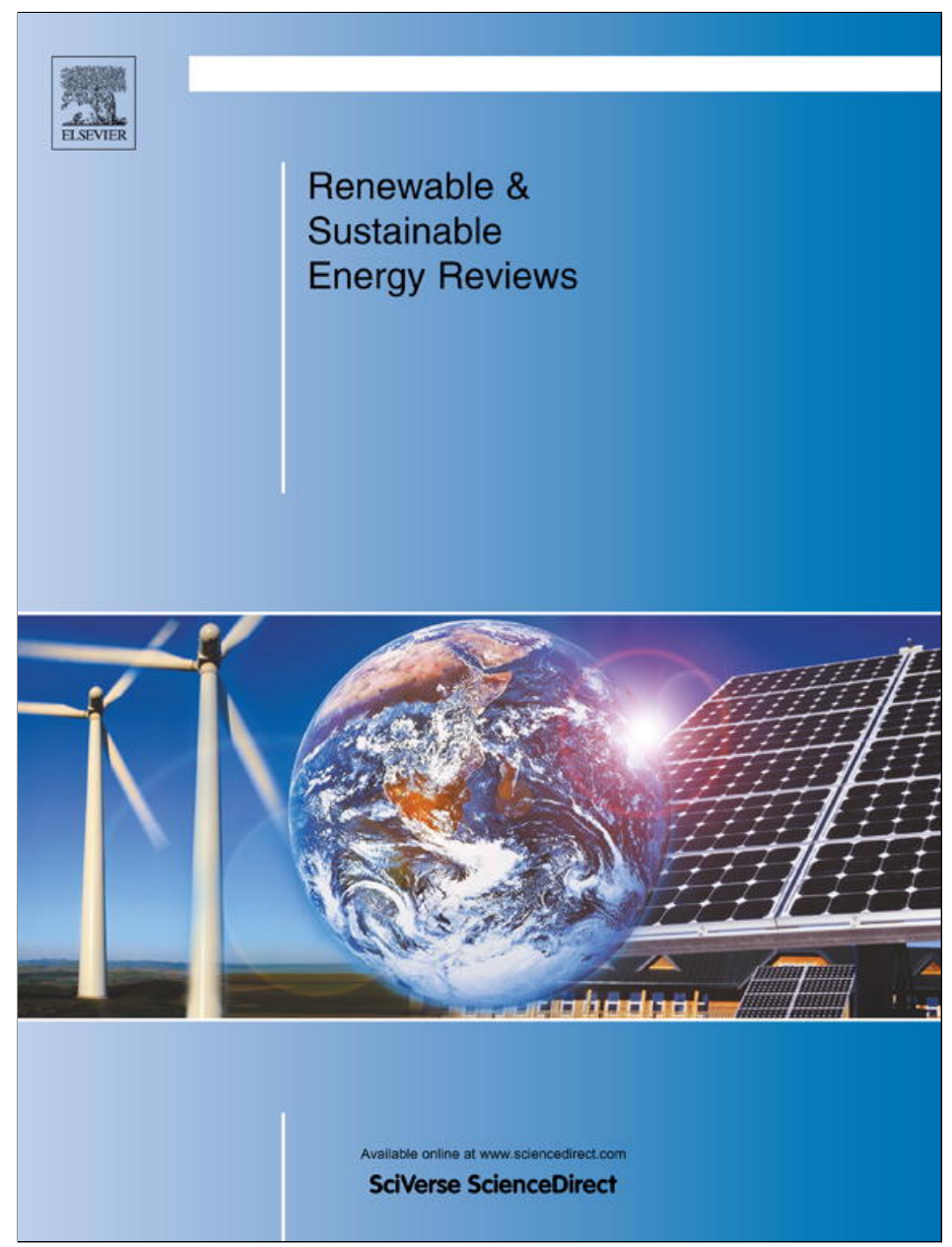

This article appeared in a journal published by Elsevier. The attached copy is furnished to the author for internal non-commercial research and education use, including for instruction at the authors institution and sharing with colleagues.

Other uses, including reproduction and distribution, or selling or licensing copies, or posting to personal, institutional or third party websites are prohibited.

In most cases authors are permitted to post their version of the article (e.g. in Word or Tex form) to their personal website or institutional repository. Authors requiring further information regarding Elsevier's archiving and manuscript policies are encouraged to visit:

http://www.elsevier.com/authorsrights 


\title{
Indicators for sustainable energy development: A multivariate cointegration and causality analysis from Tunisian road transport sector
}

\author{
Khaled Ben Abdallah ${ }^{\mathrm{a}}$, Mounir Belloumi ${ }^{\mathrm{b}, *}$, Daniel De Wolf ${ }^{\mathrm{c}}$ \\ a Higher Institute of Transport and Logistics of Sousse, University of Sousse, Tunisia \\ ${ }^{\mathrm{b}}$ Faculty of Administrative Sciences, Najran University, Saudi Arabia and LAMIDED, University of Sousse, Tunisia \\ ${ }^{\mathrm{c}}$ Faculty of Economics and Management and TVES, University of Littoral, France
}

\section{A R T I C L E I N F O}

\section{Article history:}

Received 8 December 2012

Received in revised form

14 March 2013

Accepted 18 March 2013

\section{Keywords:}

Sustainable energy development

Johansen's cointegration approach

Environmental Kuznets curve

Transport sector

Tunisia

\begin{abstract}
A B S T R A C T
This paper studies causal mechanism between indicators for sustainable energy development related to energy consumption from Tunisian road transport sector. The investigation is made using the Johansen cointegration technique and the environmental Kuznets curve (EKC) approach. It examines the nexus between transport value added, road transport-related energy consumption, road infrastructure, fuel price and $\mathrm{CO}_{2}$ emissions from Tunisian transport sector during the period of 1980-2010.

Empirical results show that road transport-related energy consumption, transport value added, transport $\mathrm{CO}_{2}$ emissions and road infrastructure are mutually causal in the long-run. These results do not support the hypothesis of neutrality between energy and income for the Tunisian road transport sector. Also, there is a unidirectional causality running from fuel price to road transport-related energy consumption with no feedback in both the short and long runs. The fuel price and the road infrastructure are significant in the causal chain. Though the estimated long-run cointegrated equation, we conclude that there is an inverse $\mathrm{N}$-shaped relation between transport value added and transport $\mathrm{CO}_{2}$ emissions, with income turning point respectively equal to 75 and 579 (constant 2000 TND prices). Therefore, our empirical findings refute the hypothesis of an inverted $U$-shaped EKC for transport $\mathrm{CO}_{2}$ emissions in Tunisia.

The findings of this study have a number of policy implications. Economic growth, environmental degradation, energy and transportation policies should be recognized in order to improve the energy efficiency in transport sector. All measures that should reduce petroleum consumption and greenhouse gas emissions without affecting economic growth may be undertaken. The policymakers in Tunisia should plan urban transport, relocate production units, improve fuel-efficient vehicles and reinforce legislation on controlling emissions in order to copying with policies based on low-carbon development and climate-resilient strategies.
\end{abstract}

(c) 2013 Elsevier Ltd. All rights reserved.

\section{Contents}

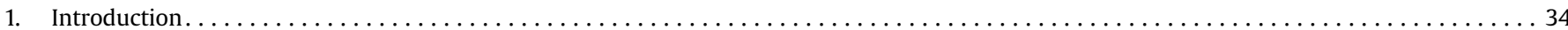

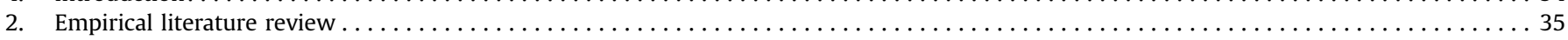

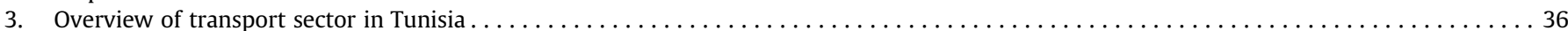

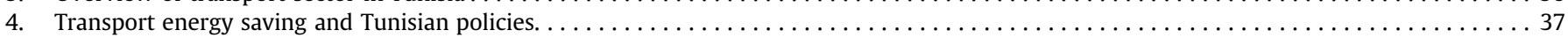

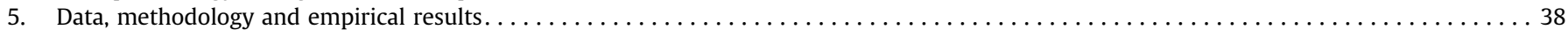

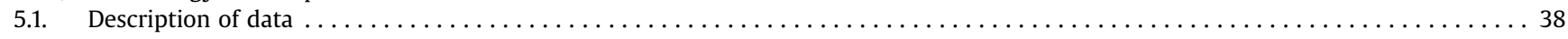

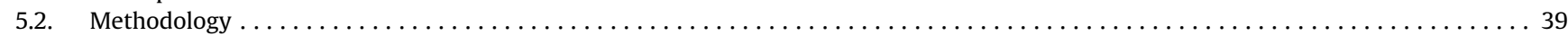

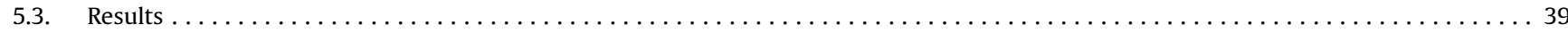

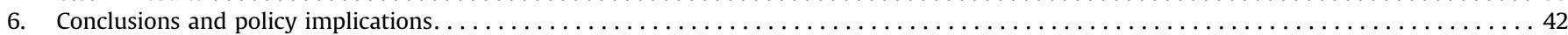

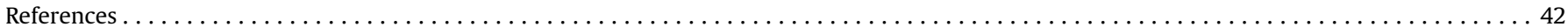

\section{Introduction}

\footnotetext{
* Corresponding author. Tel.: +966530948710; fax: +96675428887 .

E-mail addresses: mounir.balloumi@gmail.com, mounir.belloumi@fdseps.rnu.tn (M. Belloumi).
}

The energy sustainability requires development modes which provide reliable energy services at a less cost, demand few of 
energy and produce few of polluting gas. Energy consumption is a serious problem for developing countries and it is strongly linked to gas emissions. Consequently, economic growth, which uses more energy and produces more pollutant gas, is considered unsustainable and it affects negatively public health [1-7]. Since 1999, IAEA [8-10] has been working on the construction of socio-economic and environmental indicators for sustainable energy development. Economic, demographic, urban, and technological factors can influence energy consumption and so as gas emissions [11-15].

To evaluate the energy sustainability degree of transport sector, it is necessary to determine the driving factors influencing transport-related energy consumption such as economic growth, energy price, urban population, transport activity, motorization rate, traveling distance, park structure, vehicle types, vehicle age, urbanization, national road network and transport intensity. The main objective was to define cause and effect relationships between these indicators in order to formulate appropriate policies increasing the energy sustainability in the transport sector.

Recently, interest in the causality question has gained more attention to the concerns about climate change with following proposals to limit $\mathrm{CO}_{2}$ emissions by restricting fossil fuel consumption. Literature on this topic has been interested in an aggregate and disaggregates contexts. More existing methods have presented to examine the causal mechanisms between energy consumption, economic growth, environmental degradation and social development.

Although transport sector is considered an important consumer of energy, this problematic is empirically less studied in the sustainable transport literature. In this sense, three principal approaches are adopted: the cointegration and causality analysis, environmental Kuznets curve model and the decomposing analysis method.

In Tunisia, energy consumption related to the transport activity is still continuous to increase with a share more than $34 \%$ of total energy consumption in 2010 [16]. Road transport is considered the important source responsible for combustible fossils consumption with a share of more than $70 \%$ of total transport related energy consumption in 2010. Consequently, its contribution in total $\mathrm{CO}_{2}$ emissions is important comparatively to other activities. The $\mathrm{CO}_{2}$ emissions from road transport have increased from 1.75 million metric tons in 1980 to 4.94 million metric tons in 2010, representing more than $27 \%$ of total $\mathrm{CO}_{2}$ emissions [16]. Road transportation affects environment by emitting greenhouse gases, and environment also affects road transportation through climate change.

Transport sector has to meet many challenges. It has to fulfill the challenge of economy, society and environment. This suggests that government in Tunisia should elaborate some strategies in order to reduce its energy consumption and to make it more sustainable. Action is needed to restrict the use of fossil fuels: Tunisian Government should elaborate a sustainable transport strategy that takes into account the rising of fossil fuels consumption and the negative effects of $\mathrm{CO}_{2}$ emissions at the same time.

Different measures have been proposed for sustainable transport to copy with climate policy. They are classified into two policy measures-renewable energy development (such as bio-fuels) versus reduction of energy consumption. The restriction of transport-related energy consumption can be achieved by using economic instruments such as fuel or carbon taxes. However, the strategy of reducing transport energy consumption can have negative effects on economic growth. Policy makers should be aware of the nexus between transport energy and economic growth for both energy and environmental policies.

This paper studies causal mechanism between per capita transport value added (PCTVA), per capita road transport-related energy consumption (PCRTEC), per capita road infrastructure (PCRI), per capita $\mathrm{CO}_{2}$ emissions from Tunisian transport sector
$\left(\mathrm{PCTCO}_{2}\right)$ and fuel price (FPrice) during the period 1980-2010 using the cointegration technique and Environmental Kuznets Curve model. We consider a multivariate model rather than the usual bivariate approach in order to investigate other channels in the causal links between indicators for sustainable energy development from the Tunisian road transport sector. Our study is one of the few studies which focus on the relationship between energy consumption, GDP and $\mathrm{CO}_{2}$ emissions on disaggregated level. The choice of transport sector is guided by the strong connection between road transportation and sustainable development. Its purpose is to provide an insight for policy-makers in the choice and the implementation of adequate strategy reducing road energy consumption. For example, if causality runs from road transport energy consumption to transport value added, then restricting its use may impede transport GDP. However, if such causality direction runs only from transport GDP to road transport energy, then a conservation policy may be desirable.

The remainder of the paper is organized as follows: Section 2 presents a review of literature on relationships between various indicators for sustainable energy development. It also outlines some methods used in order to analyze the interaction between transport, energy, economic and environment areas. Section 3 describes Tunisia's transport activity in order to show the evolution of the indicators for sustainable energy development during the period 1980-2010. Section 4 presents policies adopted in Tunisia to reduce the use of energy in the transport sector. In Section 5, we present the data, the methodology and analyze the empirical results.

\section{Empirical literature review}

In literature, a large majority of studies [17-19] have discussed the question for relationship between transport activity, economic growth and environmental effects in order to elaborate an efficient transport policy [20-22]. Literature review shows several approaches such as causality test, environmental Kuznets curve model and decomposing analysis.

Concerning causality tests, studies show many controversies in terms of causality sense. The causal relationships can be unidirectional or bidirectional or absent. The divergence of results is mainly attributed to the difference of empirical methods used and the choice of period of study. Since the original paper of Kraft and Kraft [23], many empirical works have analyzed the cointegration relationship between economic growth and energy consumption [24-30].

For the case of Iran, Lotfalipour et al. [31] have studied the causal relationships between economic growth, carbon mission and fossil fuels consumption during the period 1967-2007. The energy consumption has been decomposed into three components: total consumption of fossil fuels, petroleum products and natural gas. The authors have found a unidirectional causality from economic growth, petroleum products and natural gas consumption to carbon emissions. Also, they have found that carbon emissions, petroleum products and total fossil fuels consumption are not cointegrated to economic growth. The most important implication is the independence between energy and economic growth. In Tunisia, Belloumi [32] has examined the same problematic along the period 19712004 by using the Johansen cointegration technique. He has shown a unidirectional causality from economic growth to GDP in the shortrun and bidirectional causality in the long-run.

Gas emissions are strongly linked to energy consumption especially fossils combustibles [33]. Environmental impacts caused by gas emissions due to energy consumption depend on quantities of energy required by economic growth. Consequently, economic growth, that use more energy and produce more pollutant gas, is 
considered unsustainable and affect negatively public health. In this context, several studies have been elaborated in order to analyze the relationship between economic growth and gas emissions. The relationship between economic growth and $\mathrm{CO}_{2}$ emissions has been treated by several studies [34-36]. The original approach which links economic growth to social development has presented by Kuznets [37]. However, Grossman and Krueger [38] have applied this approach in order to evaluate the environmental policies. The relationship between economic growth and $\mathrm{CO}_{2}$ emissions has been treated and they have suggested that this relationship can be illustrated by an inverted- $U$ curve and it is known as the Kuznets curve. The general finding stipules that the increase of domestic income can ameliorate the environmental situation. In addition, pollution increases during the first phases of economic growth. For the case of Tunisia, Fodha and Zaghdoud [39] have studied the relationship between economic growth and gas emissions over the period 1961-2004. Their study is based on EKC hypothesis and it uses the time series technique. Particularly, they have treated the relationship between $\mathrm{CO}_{2}$ and $\mathrm{SO}_{2}$, as an environmental indicators, and economic growth. They have found a long-run co-integration relation between the gas emissions and GDP per capita. The two relations between $\mathrm{SO}_{2}$ emissions and GDP per capita and between $\mathrm{CO}_{2}$ and GDP per capita, have taken the form of inversed $N$. For the two cases, the two turning points have been realized, respectively, at $1200 \$$ and 3700 \$ (constant price of 2000).

For the case of transport, the relationship between economic growth, transport energy consumption and $\mathrm{CO}_{2}$ emissions has been treated recently. Generally, Kolb and Wacker [40] have been interested by measuring energy consumption of freight transport by road and production of $\mathrm{CO}_{2}$. In order to save fuel in transport activity, Leonardi and Baumgartner [41] have summarized some strategies such as logistic efficiency, vehicles efficiency, driver efficiency, and road efficiency. Schipper et al. [42] have presented an important methodology to detecting the parameters that effect transport emissions. For the case of South Africa, Akinboade et al. [43] have used the cointegration techniques in order to analyze the long-run relationship among the variables which explicating the aggregate gasoline demand function over the period 19782005. The results confirm the existence of a cointegration relationship. The estimation of price and income elasticities of gasoline demand serves to develop appropriate energy policy. The estimated elasticities show that gasoline demand in South Africa is price and income inelastic. The important policy implication is the unreliability of the public transport system in South Africa.

For the case of England, Sorrell et al. [44] have found during the period 1989-2004 that increasing of vehicle transportation capacity and reducing of vehicle average energy consumption have improved the energy efficiency. However, Lu et al. [45] have estimated the development trends of the number of motor vehicles, vehicular energy consumption and $\mathrm{CO}_{2}$ emissions in Taiwan during 2007-2025. They have adopted simulation of different economic growth scenarios in order to explore the influence of economic growth on energy consumption.

For china, Yaobin [46] explains cointegration relationship between energy consumption, population growth, economic growth and urbanization process over the period between 1978 and 2008. The results show a unidirectional Granger causality running from urbanization to energy consumption both in the long and short run. Also, Pongthanaisawan and Sorapipatana [47] have analyzed the relationship between motorcycle and car ownerships and level of economic development in Thailand. They study the impacts of this relationship on fuel consumption and greenhouse gas emissions. Using semi-parametric techniques, the authors have shown that economic development affects the ownership of private vehicles and so fuel consumption and gas emissions. The interesting conclusion of their study is that the improve of public transport system leads to reducing the traffic mobility of private vehicles, promotion of the vehicle efficiency and so reducing fuel consumption and gas emissions. In this sense, Yan and Crookes [48] have forecasted the future trends of energy demand of road vehicle and emissions under various strategies for reducing the impacts of china's road vehicles on energy resources and environment. These strategies have concerned on the fuel economy regulation, alternative fuels and vehicles, public and non-motorized transport and economic incentives.

Over the period 1970-2007, Rudra [49] discussed the causality relationship between transport infrastructure, energy consumption and economic growth in India. The unidirectional causality from transport infrastructure to energy consumption implies that energy and transportation policies must be recognized. However, Niovi et al. [50] estimate the effect of the spatial structure of the economy and the degree of spatial concentration of activities on fuel demand by using decomposition analysis. The results show that urban density increases fuel consumption. In addition, Marshall et al. [51] explore the causal relationship between residential location and vehicle miles of travel, energy consumption and $\mathrm{CO}_{2}$ emissions in Chicago metropolitan area over the period 2007-2008. In the same context, Reinhard and Yasin [52] concluded that urban energy planning and urbanization management are strongly linked and must be coordinated to lead to sustainable energy development.

In the literature, many studies are interested on the relationship between gas emissions and economic growth using the EKC model [53-59]. Therefore, a few studies are interested on transport sector. The original study of Cole et al. [60] confirms the EKC hypothesis between per capita income and local air pollutants from transport sector for European countries over the period 1970-1992. Also, Hilton and Levinson [61] find that the relationship between economic growth and plumb emissions from transport sector supports the EKC model for 48 countries during 20 years. During the period 1980-1995, Tanishita and Miyoshi [62] find that the relationship between the energy intensity of private and public transportation and the per capita Gross Regional Product verified the EKC model corresponding to an inverted $U$ shape of the EKC. Since 1998, the notion of urban EKC is emerged. Especially, Kahn [63] mentioned that the private mobility, related to economic growth, increase of hydrocarbon emissions from urban traffic in California State.

\section{Overview of transport sector in Tunisia}

The transport is one of the major economic activities which consume a big part of energy. In Tunisia, transport sector takes the second place in terms of energy consumption with 34\% of total energy consumption in 2010 after industrial sector (35\%).

Table 1

Sectoral energy consumption in Tunisia during 1980-2010. Source: authors' calculation based on $[16,64]$.

\begin{tabular}{lllll}
\hline & $1980(\%)$ & $1990(\%)$ & $2000(\%)$ & $2010(\%)$ \\
\hline $\begin{array}{l}\text { Total energy consumption } \\
\text { Industry }\end{array}$ & 37.8 & 39.6 & 34.9 & 35 \\
Transport & 37.2 & 30.8 & 32.3 & 34 \\
Residential & 11.4 & 14.1 & 16.9 & 16 \\
Tertiary & 8.1 & 8.6 & 8.6 & 9 \\
Agriculture & 5.5 & 6.9 & 7.3 & 6 \\
Petroleum products consumption & & & \\
Industry & 33.9 & 33.6 & 26 & 25 \\
Transport & 42.3 & 38.5 & 44 & 47 \\
Residential & 10.7 & 13.1 & 14.8 & 11 \\
Tertiary & 7.2 & 7 & 6.5 & 9 \\
Agriculture & 5.9 & 7.8 & 8.7 & 8 \\
\hline
\end{tabular}


Transport energy use increased from 827.7 ktoe in 1980 to 1.821 ktoe in 2010. Liquefied petroleum gas (LPG) and electricity were not a major fuels for transportation in Tunisia compared to petroleum products (diesel and gasoil). Transport-related petroleum consumption has increased from 826.7 ktoe in 1980 to 1.812.2 ktoe in 2010 [16]. As shown in Table 1, transport has the highest share of petroleum products consumption in total energy consumption (47\%).

In 2010, the road transport has the highest energetic consumption $(76 \%)$ compared to the railway transport (3\%). Public passenger transport energy consumption was about 38.78 Ktoe in 2010 $[16,64]$. Several factors can explain this fact: pricing and taxation of fuel used by road transport vehicles, important road infrastructure investments and vehicle's park structure. The transport sector is considered as the most important consumption of fossil combustibles with $99.5 \%$ of petroleum products consumption in 2010 (Table 2).

Road transport energy use has increased from 514 ktoe in 1980 to 1689 ktoe in 2010. The $\mathrm{CO}_{2}$ emissions from road transport have increased from 1.75 million metric tons in 1980 to 4.94 million metric tons in 2010, representing more than $27 \%$ of total $\mathrm{CO}_{2}$ emissions. This fact is explained by that road transport activity in Tunisia is closely linked to combustible fossils consumption, especially gasoline (25\%) and diesel (60.6\%) in 2010. Table 3 shows the evolution of gasoline and diesel consumption.

Growth of road transport energy use is linked to many factors such as evolution and structure of national road vehicles park, motorization, economic activity, population growth, national road network, urbanization and other factors as regulated prices of fuels. The Tunisia's vehicle's park structure is characterized by an important annual growth of car ownership numbers (6.57\%) compared to bus (less than $5 \%$ ).

Ownerships Cars Park has been rapidly increased from 118796 in 1980 to 801372 in 2010 (Table 4) increasing motorization rate from 18.60 to 75.12 (Table 5). Particularly, the ownerships cars have registered a highest growth comparatively to other road vehicles. This fact is explained by many factors, such as particular credits for ownership cars, particularly "popular cars" and leasing

Table 2

Modal mix for energy consumption from Tunisia transport sector during 19802010.

Source: authors' calculation based on $[16,64]$

\begin{tabular}{|c|c|c|c|c|}
\hline $\begin{array}{l}\text { Modal transport repartition of } \\
\text { energetic consumption }\end{array}$ & $1980(\%)$ & $1990(\%)$ & $2000(\%)$ & $2010(\%)$ \\
\hline Road & 66 & 70 & 71 & 76 \\
\hline Airway & 21 & 20 & 19 & 18 \\
\hline Maritime & 3 & 2 & 1 & 3 \\
\hline Railway & 10 & 8 & 9 & 3 \\
\hline \multicolumn{5}{|l|}{$\begin{array}{l}\text { Transport repartition consumption } \\
\text { by types of energy }\end{array}$} \\
\hline Electricity consumption & 0.1 & 0.2 & 0.6 & 0.5 \\
\hline Petroleum consumption & 99.9 & 99.8 & 99.4 & 99.5 \\
\hline
\end{tabular}

Table 3

Different types of energy consumption from Tunisian road transport sector during 1980-2010.

Source: [16].

\begin{tabular}{lrrrr}
\hline & 1980 & 1990 & 2000 & 2010 \\
\hline Total energy consumption (ktoe) & 514 & 811 & 1321 & 1689 \\
Gasoline fuel consumption (ktoe) & 152 & 264 & 391 & 434 \\
Diesel fuel consumption (ktoe) & 340 & 511 & 871 & 1024 \\
Other types of energy (ktoe) & 22 & 36 & 59 & 231 \\
\hline
\end{tabular}

Table 4

Vehicle fleet structure in Tunisia during 1980-2010.

Source: authors' calculation based on [52].

\begin{tabular}{llllll}
\hline & 1980 & 1990 & 2000 & 2010 & $\begin{array}{l}\text { Average annual } \\
\text { growth rate (\%) }\end{array}$ \\
\hline Total road vehicles & $\mathbf{2 2 2 , 9 9 4}$ & $\mathbf{3 8 8 , 7 3 8}$ & $\mathbf{7 8 9 , 3 0 8}$ & $\mathbf{1 1 6 4 , 8 2 9}$ & $\mathbf{5 . 6 6}$ \\
Car & 118,796 & 259,846 & 519,439 & 801,372 & 6.57 \\
Bus & 3718 & 5544 & 10,922 & 14,879 & 4.73 \\
Special Vehicles & 678 & 1588 & 8783 & 13,879 & 10.58 \\
Heavy Truck & 96,193 & 116,555 & 234,824 & 314,572 & 4.02 \\
Light Truck & 3609 & 5205 & 15,340 & 20,127 & 5.9 \\
\hline
\end{tabular}

Table 5

Motorization, per capita gross domestic product, urban population, urban density, road network and fuel price.

Source: authors' calculation based on [16,64].

\begin{tabular}{|c|c|c|c|c|c|}
\hline & 1980 & 1990 & 2000 & 2010 & $\begin{array}{l}\text { Average annual } \\
\text { growth rate (\%) }\end{array}$ \\
\hline $\begin{array}{l}\text { Per capita GDP } \\
\text { (constant } 2000 \text { US\$) }\end{array}$ & 1495 & 1661.29 & 2245.33 & 3165 & 2.53 \\
\hline Rate of motorization & 18.60 & 31.86 & 54.31 & 75.12 & 4.76 \\
\hline Urban density & 41.09 & 52.48 & 61.55 & 68 & 1.69 \\
\hline $\begin{array}{l}\text { Urban population } \\
(1000)\end{array}$ & 3230 & 4725 & 6066 & 7099 & 2.65 \\
\hline Road network (km) & 18010 & 20020 & 18997 & 19379 & 0.249 \\
\hline $\begin{array}{l}\text { Fuel price (Tunisian } \\
\text { dinars) }\end{array}$ & 0.205 & 0.470 & 0.653 & 1.340 & 6.45 \\
\hline
\end{tabular}

credits for road freight vehicles. Also, the car park structure is characterized by old gasoline vehicle that contribute more to $\mathrm{CO}_{2}$ emissions. The gasoline car represents more than $76 \%$ of total car park in 2010 with an average annual growth rate of 5.5\% [65].

Economic growth, motorization and road transport-related energy consumption are strongly linked. Motorization is increased at an average annual growth rate of $4.76 \%$ which can be explained particularly by growing of per capita GDP with an average annual growth rate of $2.53 \%$ (see Table 5 ).

Urban density is growing at an average annual growth rate of $1.69 \%$. Urbanized kilometers increase with growth of urban density and spatial distribution of households and activities behind the urban roads. Consequently, evolution of urbanized kilometers and road transport-related energy consumption may be high correlated [66]. All cities in Tunisia are more accessible by road which can explain the high use of road transport and so the increase of the motorization rate.

This suggests the need for reducing of energy use and so far efficient energy policy in transport activity. Tunisia's transport sector is characterized by several negative externalities especially its energy use and gas emissions. To make a sustainable transport policy, Tunisian policymakers must explain the growth of these two environmental indicators and so propose some solutions in order to improve the transport energy efficiency.

\section{Transport energy saving and Tunisian policies}

The Tunisian government sets up a series of measures to save energy in transport sector, in particular the creation of the national agency of energy conservation. Taking into account the raising of prices of energy on the international market, Tunisia must take up two challenges: the energy independence and the competitiveness of its economy. The principal objective is to contribute to a decoupling 
between progression of the gross domestic product and the consumption of energy and the diminution of the energy intensity.

On the basis of reading and analysis of the principal plans and development programs in Tunisia concerning the sector of transport, we synthesize that the promotion of sustainable transport, the rationalization of the energy consumption and promotion of new and renewable energies, the management of the natural resources and the reinforcement of the capacity of adaptation to the climate changes are the main challenges of sustainability in Tunisia.

The management of the energy demand covers all the actions likely to reduce the consumption of energy while ensuring the satisfaction of the same levels of useful energy needs, even by improving satisfaction of these needs. Five relevant actions are possible in transport sector: energy audits and contracts programs in the transport sector; stations of diagnosis of vehicles motor; formation with rational driving in the road transport; urban mobility plan; and implementation of logistic platform of freight.

The obligatory and periodic energy audit in the transport sector which started in 1986, fixes the establishments whose annual consumption is higher than 1000 toe. This initiative continues in a regular way, and touches mainly the transport companies. Thanks to this option of attenuation of emissions, possible additional energy saving, compared to the scenario of reference, would rise with 17 ktoe in 2010, and 45 ktoe in 2020 (Table 6).

The stations of diagnosis of vehicles motor make it possible to make a complete diagnosis of the performances of the motor and to prescribe with the user the operations of repair and maintenance necessary to the good performance of its vehicle. This action, which started in Tunisia in 1995, was to make it possible to install gradually, on the whole of the Tunisian territory, a sufficient number of stations of diagnosis. This action is accompanied by a broad campaign of information and sensitizing, as well as training programs and improvement of the technicians. Thanks to the actions suggested like option of attenuation of the GES, possible saving energy additional, compared to the scenario of reference, would rise with 81 ktoe in 2010, and 178 ktoe in 2020 (Table 6).

The action of formation with rational driving in road transport, which started in 1995, consisted in integrating into the examination and training level of the driving licenses, a module relating to rational control and the preventive maintenance of the vehicle. The option consists in reinforcing of the training of the monitors and inspectors to the whole of republic. Thanks to this action, it is

Table 6

Synthesis of realizable options relating to the energy saving in the transport sector (in ktoe).

Source: [67].

\begin{tabular}{lrr}
\hline & 2010 & 2020 \\
\hline Energy audits and contract programs in the transport sector & 17 & 45 \\
Stations of diagnosis of motor vehicles motor & 81 & 178 \\
Formation with rational driving in the road transport & 45 & 74 \\
Urban plans displacement & 70 & 148 \\
Implementation of logistic platform of freight & 100 & 207 \\
TOTAL & 313 & 652 \\
\hline
\end{tabular}

possible to save, compared to the scenario of reference, 45 ktoe in and 74 ktoe in 2020 (Table 6).

The action consisting to improving planning of the urban displacement can lead to additional energy saving, compared to the scenario of reference, rising to 70 ktoe in 2010, and 148 ktoe in 2020.

Thanks to the present option of implementation of logistic platform, awaited additional energy saving, compared to the scenario of reference, would rise with 207 ktoe in 2020 (Table 6).

Generally, the options saving energy in transport sector must integrate the requirements of transport in the urbanization processes in order to reduce the traversed distances, reinforce the integration of the environmental concerns on the development and the implementation of the policies and the strategies in transport sector, reduce the energy intensity and improve knowledge relating to the impacts of the climate changes on the environment and the economic growth.

\section{Data, methodology and empirical results}

\subsection{Description of data}

In this paper, we have used time series for the period 19802010. The data used include per capita transport value added (PCTVA), per capita road transport energy consumption (PCRTEC), per capita transport $\mathrm{CO}_{2}$ emissions $\left(\mathrm{PCTCO}_{2}\right)$, per capita road infrastructure (PCRI) and fuel price (FPrice). PCRTEC is expressed in terms of $\mathrm{kg}$ tone oil equivalent (ktoe). PCTVA is expressed in Tunisian national dinars (constant $2000 \mathrm{TND}$ ). $\mathrm{PCTCO}_{2}$ is expressed in metric tons. They are sourced from WDI [16]. Data concerning PCRI and FPrice are taken from $[64,68]$. For reasons of scale, we use the natural logarithm of these variables. This helps to induce stationary in the variance-covariance matrix [69].

Table 7 gives the summary statistics of each of the variables used in the analysis.

Figs. 1-5 show the trends of different indicators for sustainable energy development related to energy consumption from Tunisian road transport sector during the period 1980-2010. The five indicators present similar evolutions of long run and they are characterized by a general trend upwards. Fig. 1 shows the

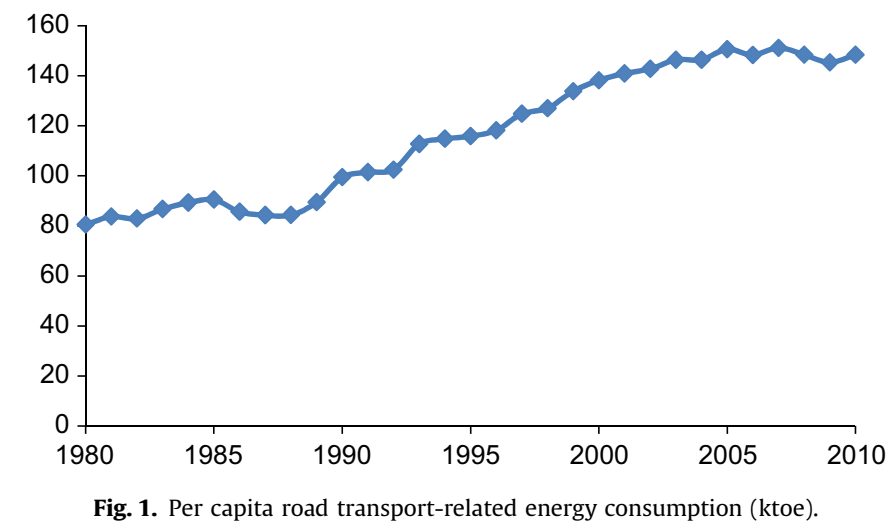

Fig. 1. Per capita road transport-related energy consumption (ktoe).

Table 7

Summary statistics.

\begin{tabular}{|c|c|c|c|c|c|}
\hline Variables & Variables description & Minimum & Maximum & Mean & Standard deviation \\
\hline PCTVA & Per capita transport value added (constant 2000 TND) & 45.09 & 371.56 & 117.03 & 110.58 \\
\hline PCRTEC & Per capita road transport energy consumption (ktoe) & 80.513 & 151.098 & 116.60 & 26.153 \\
\hline $\mathrm{PCTCO}_{2}$ & Per capita transport $\mathrm{CO}_{2}$ emissions (metric tons) & 0.274 & 0.469 & 0.363 & 0.068 \\
\hline PCRI & Per capita road infrastructure (meter) & 1.816 & 2.975 & 2.336 & 0.378 \\
\hline FPrice & Fuel price (TND) & 0.205 & 1.400 & 0.628 & 0.316 \\
\hline Observations & 31 & 31 & 31 & 31 & 31 \\
\hline
\end{tabular}




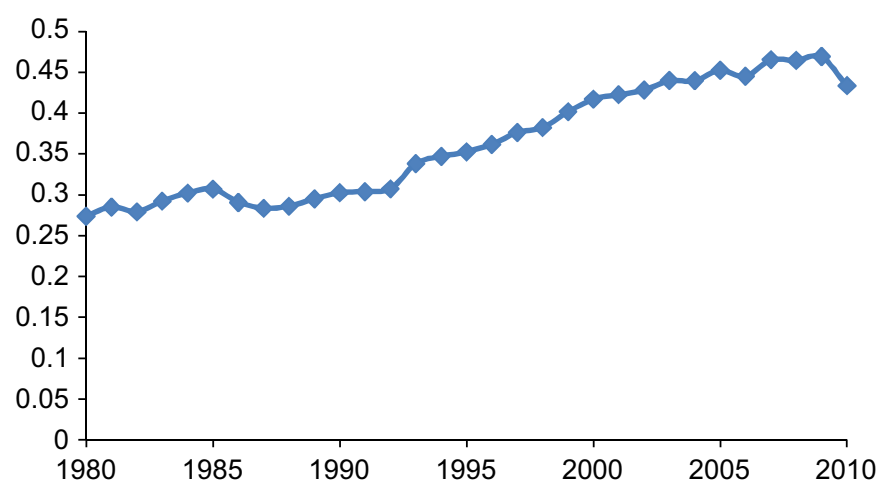

Fig. 2. Per capita transport $\mathrm{CO}_{2}$ emissions (metric tons).

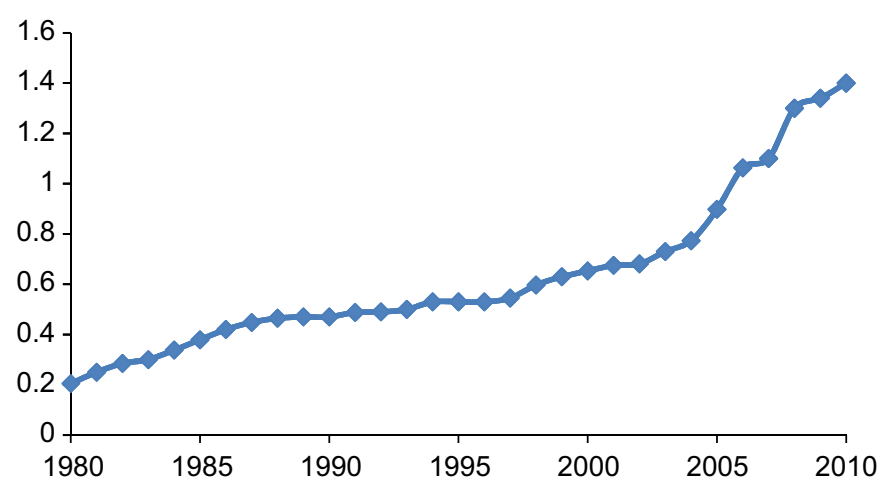

Fig. 3. Fuel price (TND).

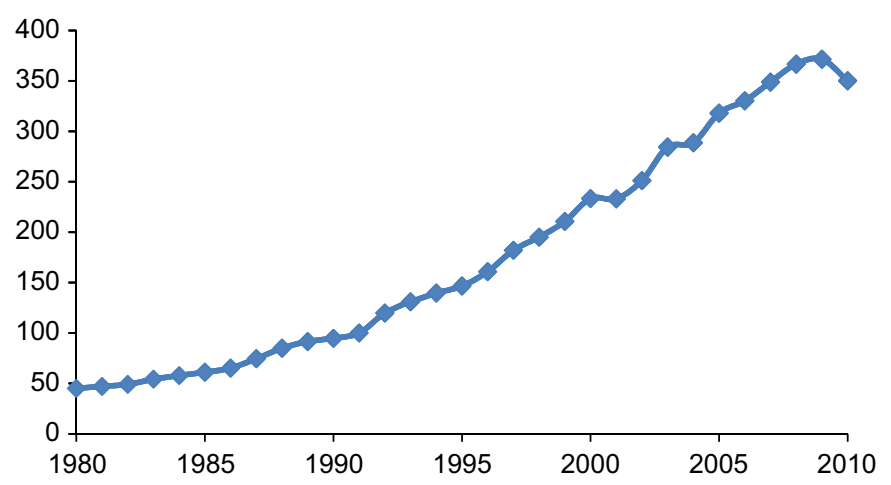

Fig. 4. Per capita transport value added (constant 2000 TND).

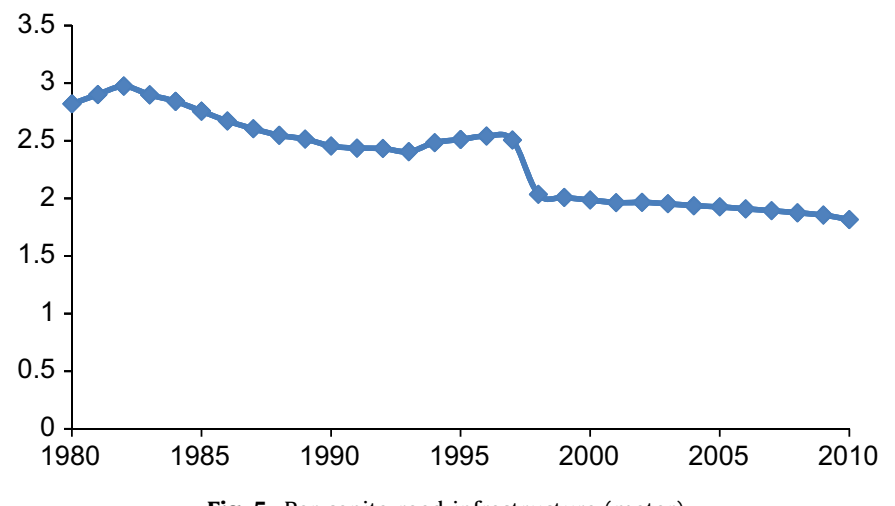

Fig. 5. Per capita road infrastructure (meter). evolution of per capita road transport-related energy consumption. It displays an important growth of road transport-related energy consumption since 1980 which is explained especially by the important growth of road vehicles parks.

Fig. 2 shows the evolution of per capita transport $\mathrm{CO}_{2}$ emissions. It indicates an increase of $\mathrm{CO}_{2}$ emissions during all the period of 1980-2010. As shown in Figs. 3 and 4, the fuel price and per capita transport value added had grown since 1980 .

Fig. 5 shows the evolution of per capita road infrastructure. It indicates a reduction of the length of the national road network since 1982 which is explained by the bad management of the investments allocated to the promotion of the road infrastructure. Generally, sectoral economic growth of transport, growth of personal motorization and infrastructure are closely linked. The road infrastructure is regarded as a factor of production of the added-value in the transport sector. It can be seems from Fig. 5 that road infrastructure do not contribute to the economic growth of transport sector, at least in the short run.

\subsection{Methodology}

The first step is to use a preliminary statistic tests to verify the stationarity for all variables. We use the usual unit root test of Dickey-Fuller (ADF) and Phillips-Perron (PP) test. The ADF test takes into account only the presence of autocorrelation in the series but the PP test considers also the hypothesis of the presence of a heteroskedasticity dimension in the time series. A time series is called non stationary if it has at least one of its moments (mean, variance, or covariance) time independent. A non stationary series possessing a stochastic unit root has to be differenced once to become stationary. This first step is essential for two reasons: the causality tests are very sensitive to the stationarity of the series [70] and most macroeconomic series are not stationary [71].

When both series are integrated of the same order, we proceed to the next step determining the lag length using the AIC and SIC criteria and examining the presence of cointegration (order of VAR). There are many possible cointegration tests: The Engle and Granger approach or the Johansen cointegration approach. The bivariate approach of Engle and Granger is very restrictive because it can be applied only if there is only one cointegrating relationship. The Johansen's cointegration test determines the number of cointegrating vectors of equations. It is based on two different likelihood ratio statistics (LR): the trace statistic and the maximum eigenvalue statistic.

Cointegration implies that causality exists between series, but it does not indicate the direction of causality. For Granger, a series "causes" another series if the knowledge of the history of the first improves the prediction of the second. We produce the VECM for all the endogenous variables in the model and use it to carry out Granger causality tests over the short and long run. The VECM can distinguish the long and short run relationship between the variables and can identify sources of causality that cannot be detected by the usual Granger causality test.

\subsection{Results}

In order to study the relationship between transport energy consumption, economic growth and $\mathrm{CO}_{2}$ emissions, we have tested the existence of unit roots in the variables using ADF and PP tests. Table 8 reports the results for both the ADF and PP test results. We conclude that, when first differences are taken, the null hypothesis of non-stationarity is rejected for all variables. The series are not stationary in levels but stationary in first difference. Hence, all variables studied are integrated of order one (I (1)). 
The optimal lag lengths in cointegrated VAR models are chosen on the basis of minimizing AIC and SC criterion. According to Parsimony low, we retain the lag length of $p^{*}=1$ (Table 9).

Given that all variables are integrated of the same order, the next step was to test for cointegration using Johansen's approach. The test results of cointegration relationship between are reported in Table 10, where $r$ represents the number of cointegrating vectors. By referring to the trace and maximum eigenvalue tests, it can be seen that, for Tunisia, results refute the null hypothesis of no cointegration relationships and confirm the presence of one cointegrating relationship at the $5 \%$ level, which means that the variables have a long-run equilibrium.

To determine the direction of causation and distinguish between "short-run" and "long-run" causality, we must examine the VECM results. The error correction model can be written by

Table 8

Results of ADF and PP unit root tests.

\begin{tabular}{llllll}
\hline \multirow{2}{*}{ Variables } & \multicolumn{2}{l}{ ADF } & & \multicolumn{2}{l}{ PP } \\
\cline { 2 - 3 } \cline { 5 - 6 } & Level & First difference & & Level & First difference \\
\hline LNPCRTEC & -0.999 & -4.356 & & -0.999 & -4.371 \\
LNPCTVA & -1.739 & -3.807 & & -1.77 & -3.807 \\
LNPCTCO $_{2}$ & -0.942 & -4.106 & & -0.942 & -4.154 \\
LNPCRI & -0.004 & -4.650 & & -0.025 & -4.566 \\
LNFPrice & -1.016 & -4.145 & & -0.951 & -4.156 \\
Critical values at 5\% & -2.963 & -2.967 & -2.963 & -2.967 \\
\hline
\end{tabular}

Note: each test uses an intercept and no trend.

Table 9

Selection of lag length.

\begin{tabular}{llll}
\hline & $\operatorname{VAR}(1)$ & $\operatorname{VAR}(2)$ & $\operatorname{VAR}(3)$ \\
\hline AIC criterion & -19.322 & -19.387 & $-20.130^{*}$ \\
Schwarz criterion (SC) & $-17.895^{*}$ & -16.770 & -16.323 \\
\hline
\end{tabular}

* Indicates lag order selected by the AIC and SC criterion

Table 10

Results of Johansen cointegration tests.

\begin{tabular}{|c|c|c|c|c|c|}
\hline \multirow[t]{2}{*}{ Eigenvalue } & \multirow[t]{2}{*}{$H_{0}: r$} & \multirow[t]{2}{*}{ Trace } & \multirow[t]{2}{*}{$\lambda$-max } & \multicolumn{2}{|c|}{ Critical values at $5 \%$} \\
\hline & & & & Trace & $\lambda$-max \\
\hline 0.697 & 0 & 77.704 & 34.709 & 69.818 & 33.876 \\
\hline 0.515 & 1 & 42.995 & 20.994 & 47.856 & 27.584 \\
\hline
\end{tabular}

Note: $r$ indicates the number of cointegrating relationships. The critical values for trace test statistics are given by Johansen and Juselius [72].

Trace test indicates 1 cointegrating equation at the 0.05 level.

Max-eigenvalue test indicates 1 cointegrating equation at the 0.05 level. the following equations:

$$
\begin{aligned}
\Delta Y_{t}= & \beta_{10}+\sum_{1}^{K 11} \beta_{11 i} \Delta Y_{t-i}+\sum_{1}^{K 12} \beta_{12 j} \Delta X_{t-j}+\sum_{1}^{K 13} \beta_{13 r} \Delta Z_{t-r} \\
& +\sum_{1}^{K 14} \beta_{14 n} \Delta U_{t-n}+\sum_{1}^{K 15} \beta_{15 m} \Delta V_{t-m}+\beta_{16} E C T_{t-1}+\mu_{1 t} \\
\Delta X_{t}= & \beta_{20}+\sum_{1}^{K 21} \beta_{21 i} \Delta X_{t-i}+\sum_{1}^{K 22} \beta_{22 j} \Delta Y_{t-j}+\sum_{1}^{K 23} \beta_{23 r} \Delta Z_{t-r} \\
& +\sum_{1}^{K 24} \beta_{24 n} \Delta U_{t-n}+\sum_{1}^{K 25} \beta_{25 m} \Delta V_{t-m}+\beta_{26} E C T_{t-1}+\mu_{2 t} \\
\Delta Z_{t}= & \beta_{30}+\sum_{1}^{K 31} \beta_{31 i} \Delta X_{t-i}+\sum_{1}^{K 32} \beta_{32 j} \Delta Y_{t-j}+\sum_{1}^{K 33} \beta_{33 r} \Delta Z_{t-r} \\
& +\sum_{1}^{K 34} \beta_{34 n} \Delta U_{t-n}+\sum_{1}^{K 35} \beta_{35 m} \Delta V_{t-m}+\beta_{36} E C T_{t-1}+\mu_{3 t} \\
\Delta U_{t}= & \beta_{40}+\sum_{1}^{K 4} \beta_{41 i} \Delta X_{t-i}+\sum_{1}^{K 42} \beta_{42 j} \Delta Y_{t-j}+\sum_{1}^{K 43} \beta_{43 r} \Delta Z_{t-r} \\
& +\sum_{1}^{K 44} \beta_{44 m} \Delta V_{t-m}+\sum_{1}^{K 45} \beta_{45 n} \Delta U_{t-n}+\beta_{46} E C T_{t-1}+\mu_{4 t} \\
\Delta V_{t}= & \beta_{50}+\sum_{1}^{K 51} \beta_{51 i} \Delta X_{t-i}+\sum_{1}^{K 52} \beta_{52 j} \Delta Y_{t-j}+\sum_{1}^{K 53} \beta_{53 r} \Delta Z_{t-r} \\
& +\sum_{1}^{K 54} \beta_{54 m} \Delta V_{t-m}+\sum_{1}^{K 55} \beta_{55 n} \Delta U_{t-n}+\beta_{56} E C T_{t-1}+\mu_{5 t}
\end{aligned}
$$

where $Y_{t}, X_{t}, Z_{t}, U_{t}, V_{t}$ and $\mu_{t}$ denote respectively PCTVA, PCTREC, $\mathrm{PCTCO}_{2}$, PCRI, FPrice and the error term that follows a Gaussian white noise. In addition, $\Delta$ and $E C T$ are respectively the difference operator and the error correction term. The significance of coefficients $\left(\beta_{i}\right)$ of the explanatory variables is mentioned as the presence of causality in the short run.

The sources of causality can be identified from the significance test of the coefficients of independent variables in the VECM. Regarding the causality of the short-run, we can test the nullity of the parameters associated with independent variables in each equation of VECM using the $\chi^{2}$-Wald statistics. The Causality in the long-run can be tested by the significance of the speed of adjustment. We use the $t$-statistics of the coefficients of the ECT which indicate if there are long-run causal effects. Results of Granger causality tests are given in Table 11 .

The results of causality between indicators for sustainable energy development in transport sector in Tunisia are shown in Fig. 6.

\begin{tabular}{|c|c|c|c|c|c|c|}
\hline \multirow[t]{2}{*}{ Dependent variable } & \multicolumn{5}{|c|}{ Source of causation (short-run) } & \multirow{2}{*}{$\begin{array}{l}\text { Source of causation (long-run) } \\
\text { ECT }\end{array}$} \\
\hline & $\Delta Y_{t}$ & $\Delta X_{t}$ & $\Delta Z_{t}$ & $\Delta U_{t}$ & $\Delta V_{t}$ & \\
\hline$\Delta Y_{t}$ & - & $0.129(0.718)$ & $0.319(0.572)$ & $0.133(0.715)$ & $0.163(0.685)$ & $-0.493[-2.074]$ \\
\hline$\Delta X_{t}$ & $0.014(0.902)$ & - & $0.487(0.485)$ & $0.066(0.796)$ & $2.568(0.109)$ & $-0.363[-2.325]$ \\
\hline$\Delta Z_{t}$ & $0.505(0.477)$ & $0.265(0.606)$ & - & $0.014(0.905)$ & $0.0001(0.991)$ & $-0.327[-1.927]$ \\
\hline$\Delta U_{t}$ & $6.641(0.010)$ & $4.319(0.037)$ & $5.383(0.020)$ & - & $2.681(0.101)$ & $-0.694[-3.288]$ \\
\hline$\Delta V_{t}$ & $1.012(0.314)$ & $0.741(0.389)$ & $0.0001(0.990)$ & $0.334(0.563)$ & - & $0.532[2.139]$ \\
\hline
\end{tabular}

We show the existence of unidirectional causality running from fuel price to road transport-related energy consumption with no feedback both in the short and long run. The price policy of fuel in Tunisia is characterized by the absence of taxation in the price structure. The fuel price presents a source of motivation of the individual mobility [73]. In the case of Tunisia, road transport-related energy consumption and transport value added are mutually causal

Table 11

Granger causality tests.

Note: Numbers in square brackets are $t$-statistics, while those in parentheses are $p$-values. 


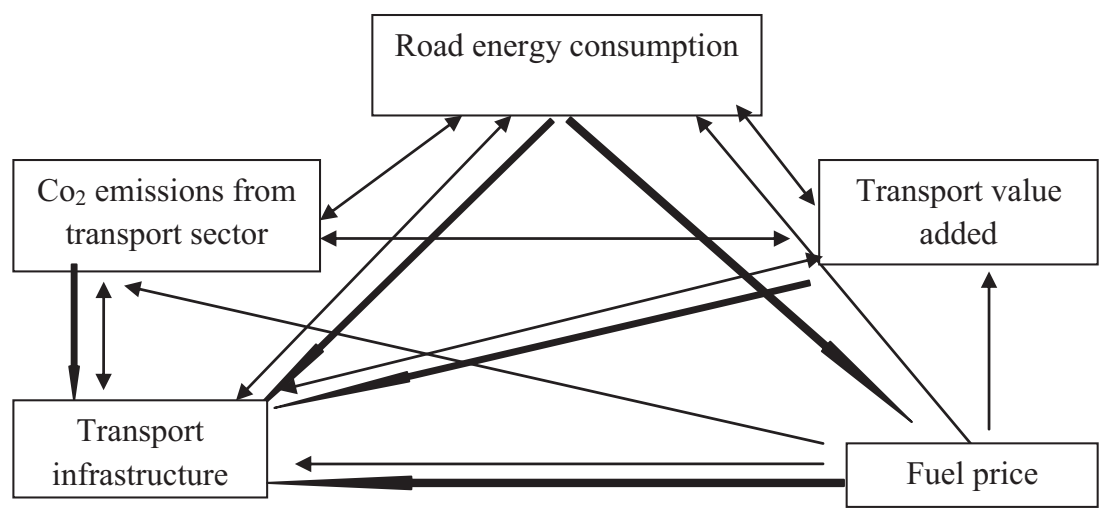

Fig. 6. Causality between indicators for sustainable energy development related to energy consumption from Tunisian road transport sector.

in the long-run. The study seems to reject the neo-classical assumption that energy is neutral to growth [74]. The neutrality is observed only in the short run. The feedback between the two series implies that a high level of economic growth in transport sector leads to a high level of fuel demand and vice versa. In Tunisia road transport sector, the policy of "energy must lead economic growth" should be reinforced for a long period [32].

The standard Granger tests would have concluded that there is bidirectional causality between road transport-related energy consumption transport and road infrastructure. The energy consumption in transport sector presents, at the same time, the cause and the results of urbanization structure, the spatial distribution of households and activities, urban density, the urbanized kilometers and specially the road infrastructure. Our results are consistent with the finding of $[46,49-52]$.

It can be seen that the relationship causality between road transport-related energy consumption and transport $\mathrm{CO}_{2}$ emissions is bidirectional. This result implies that energy consumption affects environment. The Granger causality from $\mathrm{CO}_{2}$ emission to the transport value added can be explained by the fact that an increase in $\mathrm{CO}_{2}$ emission is linked to an increase of input use of fossil fuels in the transport sector $[33,48]$. We might expect that increased transport GDP will also increase the demand for energy use and indirectly increase of $\mathrm{CO}_{2}$ emission.

In order to analyze the relationship between $\mathrm{PCTCO}_{2}$ and PCTVA, we have choice to test hypothesis of EKC model. The Standard model of EKC can be expressed as

$$
\operatorname{lnPCTCO}_{2 t}=\Delta+\beta_{1} \operatorname{lnPCTVA}_{t}+\beta_{2}\left(\operatorname{lnPCTVA}_{t}\right)^{2}+\beta_{3}\left(\operatorname{lnPCTVA}_{t}\right)^{3}+\varepsilon_{t}
$$

where $\ln$ is the natural logarithm and $\varepsilon_{t}$ and $\Delta$ are respectively the error terms and the constant. The first econometric problem is related to the choice of the degree of the equation. Some studies consider only a cubic equation of income per capita as those of $[75,76]$ or a quadratic equation such as studies of [77-80]. Other econometric studies estimate several empirical models (linear, quadratic and cubic). The significance of the cubic per capita income is based on the assumption of an $N$ relation. The inverted- $U$ relationship implies that pollution is reduced and environmental quality improves beyond a certain threshold of income per capita. Therefore, it is essential to start from a third level function of per capita income and to verify the significance of the coefficient of cubic variable. If it was significant, estimating a cubic equation is accepted. Table 12 presents the EKC estimation results.
Table 12

EKC estimation results.

\begin{tabular}{lc}
\hline Coefficients & Cubic specification estimators \\
\hline$\beta_{0}$ & $24.872(0.000)$ \\
$\beta_{1}$ & $-7.770(0.001)$ \\
$\beta_{2}$ & $1.584(0.001)$ \\
$\beta_{3}$ & $-0.102(0.000)$ \\
\hline
\end{tabular}

Note: Numbers in parentheses are $p$-values.

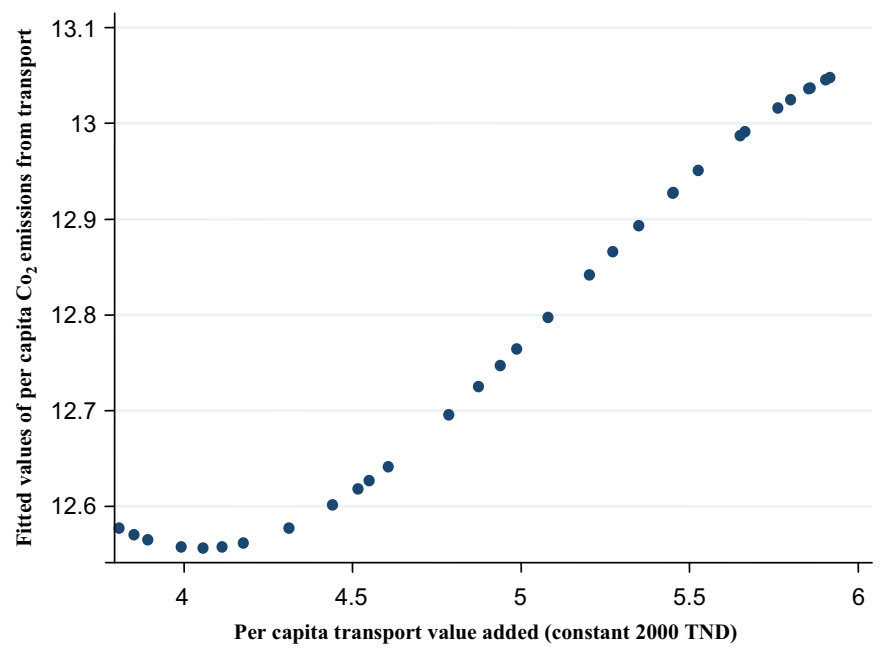

Fig. 7. Environmental Kuznets curve.

Though the estimated long-run cointegrated equation, we denote that there is an inverse $\mathrm{N}$-shaped relation between transport value added and transport $\mathrm{CO}_{2}$ emissions because $\beta_{1}<0, \beta_{2}>0$ and $\beta_{3}<0$ (Fig. 7).

In our case, the two income turning points are respectively equal to 74.88 and 578.82 (constant 2000 TND prices). Therefore, our empirical findings refute the hypothesis of an inverted $U$ shaped EKC for transport $\mathrm{CO}_{2}$ emissions in Tunisia. However, this relation seems to be a monotonically increasing curve because we find that the first turning point is very low and the second turning point is outside the data set [39]. 


\section{Conclusions and policy implications}

In this paper, we are interested to the relationship between indicators for sustainable energy development related to energy consumption from Tunisian road transport sector. We studied the relationship between transport value added, road transport-related energy consumption, road infrastructure, fuel price and $\mathrm{CO}_{2}$ emissions from Tunisian transport sector during the period 1980-2010. To this end, we have chosen to test the causality relationship in the short- and long-run in the first step, and to test the validity of EKC hypothesis in the second step. From the test results, we conclude that there is a long-run mutual causal relationship between transport value added, road transportrelated energy consumption transport, road infrastructure and $\mathrm{CO}_{2}$ emissions from the Tunisian transport sector.

In general, the study results do not support the hypothesis of neutrality between road transport-related energy consumption and transport value added in the long-run. Tunisia's economic growth is closely dependent on increasing of transport fuel consumption [81]. Consequently, we conclude that increase of transport demand, which is required by economic growth, leads to more fuel use by freight and passengers transport. In fact, increase of transport intensity leads to more kilometers traveled and so more use of fossil energy. Then Tunisia's transport sector is characterized by more problems such as current logistic organization which cannot give optimal solutions for reducing road traveled distances, operating management problem characterized especially by the absence of transport planning and modal disequilibrium problem which favorite the road transport. This result can be explained by the insufficiencies of the regulatory instruments: Restrictions of the use of private cars and the encouragements of transport energy saving seems not appropriate to reduce energy intensity. Really, the Tunisian laws are not applied: reinforcing legislation on controlling emissions in order to copying with policies based on low-carbon development and climate-resilient strategies can help to improve the transport sector energy efficiency. More attention should be attributed to the control for ownership cars and leasing credits for road freight vehicles. The experience shows that introducing diesel passenger cars is an effective and feasible option for saving energy consumption in the road transport sector, cutting down $\mathrm{CO}_{2}$ emissions and so helping in improving socio-economic pressures [82].

The study finding of feedback between road transport-related energy consumption and road infrastructure has a number of policy implications. The Tunisian policymakers have adopted a transport policy based on the development of transport infrastructure which motives more and more the use of private cars and the increase of the number of traversed kilometers. Considering the importance of the road transport-related energy consumption in urban areas, local authorities have adopted, in order to make sustainable their transport system, the development of road networks investment. This solution of urban transport planning is considered not appropriate to reduce personal motorization, considering the bad supply and quality of public transport.

The finding of bidirectional causality between road transportrelated energy consumption transport and $\mathrm{CO}_{2}$ emissions from Tunisian transport sector are consistent with the Tunisian reality. More attention should be attributed to the problem of absence of sensitizing to environmental problem. A conservative policy for transport energy would be detrimental to long-run transport GDP. Energy and climate policies which are devoted towards a reduction in GHGs should emphasize the use of alternative sources rather than exclusively attempt to reduce overall energy consumption. The development of bio-fuels is, therefore, a promising avenue to ensure an adequate supply of energy to sustain economic development.
Thus, there is unidirectional causality running from fuel price to road transport-related energy consumption both in the short and long-run. Then, taxation of fossils fuels can increase the personal fuel expenditures and so encouraging the substitution of collective transportation to individual transportation. Fuel taxes can be used as economic instruments to encourage the public transport and to promote the use of clean vehicles with high capacities, less energy consumption in order to substitute of the clean fuels to fossil fuels.

This study can be used for helping the decision makers to provide a sustainable policy of transport which aim to reduce energy consumption and $\mathrm{CO}_{2}$ emissions of Tunisia's transport sector. Tunisian authorities are aware of the urgency to implement measures that saving fuel. The Granger-causality tests conclude that energy and climate policies which are devoted towards a reduction in GHGs should emphasize the use of alternative sources rather than exclusively attempt to reduce energy consumption. Policy makers can be trapped in reducing fossil fuels used in the transport sector, through restricting mobility as a climate and energy policy. Policymakers should integrate socio-economic and environmental dimensions in their strategy to improve the energy efficiency in transport sector. They should think to logistic solutions such as relocation of production units and optimization of vehicle routing problem, to modal shifting by improvement of the supply and the quality of public transport, to the coupling and decoupling phenomenon between transport activity and the economic growth and to clean Technologies based on fuel economy. The several decisions concerning land use planning, transport planning, energy policy, price policy, economic policy, environmental protection and social development have a significant impacts on saving energy from road transport and their environmental effects in order to maintain sustainable energy development in the transport sector.

\section{References}

[1] You J. China's energy consumption and sustainable development: comparative evidence from GDP and genuine savings. Renewable and Sustainable Energy Reviews 2011;15:2984-9.

[2] Jaber JO, Al-Ghandoor A, Sawalha SA. Energy analysis and energy utilization in the transportation sector of Jordon. Energy Policy 2008

[3] Yan X, Crookes RJ. Energy demand and emissions from road transportation vehicles in China. Progress in Energy and Combustion Science 2010;36: 651-76.

[4] Shrestha RM, Anandarajah G, Adhikari S, Jiang K, Songli Z. Energy and environmental implications of NOx emission reduction from the transport sector of Beijing: a least-cost planning analysis. Transportation Research Part D 2005; $10: 1-11$

[5] Timilsina GR, Shrestha A. Transport sector $\mathrm{CO}_{2}$ emissions growth in Asia: Underlying factors and policy options. Energy Policy 2009;37:4523-39.

[6] Marques AC, Fuinhas JA, Goncalves BM. Dieselization and road transport $\mathrm{CO}_{2}$ emissions: evidence from Europe. Low Carbon Economy 2012;3:54-62.

[7] Singh A, Gangopadhyay S, Nanda PK, Bhattacharya S, Sharma C, Bhan C. Trends of greenhouse gas emissions from the road transport sector in India. Science of the Total Environment 2008;1:124-31.

[8] IAEA. International Atomic Energy Agency; 1999.

[9] IAEA. Energy indicators for sustainable development: guidelines and methodologies; 2005.

[10] IAEA. Energy indicators for sustainable development: country studies on Brazil, Cuba, Lithuania Mexico, Russian Federation, Slovakia and Thailand; 2007.

[11] Vera IA, Langlois LM, Rogner HH, Jalal AI, Toth FL. Indicators for sustainable energy development: an initiative by the international atomic energy agency. Natural Resources Forum 2005;29:274-83.

[12] Medina-Ross JA, Mata-Sandoval JC, Lopez-Pérez R. Indicators for sustainable energy development in Mexico. Natural Resources Forum 2005;29:308-21.

[13] Wright JC. Indicators for sustainable energy development. Center for resource management, information paper; 1991. p. 28

[14] Zen AC, Lima A, Brianchi AL, Babot L. Sustainability, energy and development: a proposal of indicators. International Journal for Infonomics 2012;5:537-41.

[15] Al-Hinti I, Al-Ghandoor A, Akash B, Sakhrieh A, Abu-Nada E. A comparative analysis of energy indicators and $\mathrm{CO}_{2}$ emissions in 15 Arab countries. International Journal of Environment and Waste Management 2013;11: 129-47. 
[16] WDI. World development indicators. Washington, DC: IBRD, World Bank; 2012.

[17] Ang JB. $\mathrm{CO}_{2}$ emissions, energy consumption and output in France. Energy Policy 2007;35:4772-8.

[18] Soytas U, Sari R, Ewing BT. Energy consumption, income, and carbon emission in the United States. Ecological Economics 2007;62:482-9.

[19] Zhang XP, Cheng XM. Energy consumption, carbone missions, and economic growth in China. Ecological Economics 2009;68:2706-12.

[20] Yuan J, Kang Y, Hu Z. Energy conservation and emissions reduction in ChinaProgress and prospective. Renewable and Sustainable Energy Reviews 2011;15:4334-47.

[21] Ong HC, Mahlia TMI, Masjuki HH. A review on energy pattern and policy for transportation sector in Malaysia. Renewable and Sustainable Energy Reviews 2012;16:532-42.

[22] Al-Ghandoor A. An approach to energy savings and improved environmental impact through restructuring Jordan's transport sector. Renewable and Sustainable Energy Reviews 2013;18:31-42.

[23] Kraft J, Kraft A. On the relationship between energy and GNP. Journal of Energy Development 1978;3:401-3.

[24] Cheng BS, Lai TW. An investigation of co-integration and causality between energy consumption and economic activity in Taiwan. Energy Economics 1997; 19:435-44.

[25] Stern D. A multivariate cointegration analysis of the role of energy in the US. Macroeconomy 2000;22:267-83.

[26] Soytas U, Sari R. Energy consumption and GDP: causality relationship in G-7 countries and emerging markets. Energy Economics 2003;25:33-7.

[27] Paul S, Bhattacharya RN. Causality between energy consumption and economic growth in India: a note on conflicting results. Energy Economics 2004;26:977-83.

[28] Mehrara M. Energy consumption and economic growth: the case of oil exporting countries. Energy Policy 2007;35:2939-45.

[29] Lise W, Van Montfort K. Energy consumption and GDP in Turkey: is there a cointegration relationship? Energy Economics 2007;29(6):1166-78.

[30] Pirlogea C, Cicea C. Econometric perspective of the energy consumption and economic growth relation in European Union. Renewable and Sustainable Energy Reviews 2012;16:5718-26.

[31] Lotfalipour MR, Falahi MA, Ashena M. Economic growth, $\mathrm{CO}_{2}$ emissions, and fossil fuels consumption in Iran. Energy 2010;35(12):5115-20.

[32] Belloumi M. Energy consumption and GDP in Tunisia: Cointegration and causality analysis. Energy Policy 2009;37:2745-53.

[33] Tanczos K, Torok A. The linkage between climate change and energy consumption of Hungary in the road transportation sector. Transport 2007; XXII(2):134-8.

[34] Agras J, Chapman D. A dynamic approach to the environmental Kuznets curve hypothesis. Ecological Economics 1999;28:267-77.

[35] Halicioglu F. An econometric study of $\mathrm{CO}_{2}$ emissions, energy consumption, income and foreign trade in Turkey. Energy Policy 2009;37:1156-64.

[36] Chang CC. A multivariate causality test of carbon dioxide emissions, energy consumption and economic growth in China. Applied Energy 2010;87:3533-7.

[37] Kuznets S. Economic growth and income inequality. American Economic Review 1955;65:1-28

[38] Grossman GM, Krueger AB. Environmental impacts of a North American free trade agreement. Working paper no. 3194. Cambridge: National Bureau of Economics Research; 1991.

[39] Fodha M, Zaghdoud O. Economic growth and pollutant emissions in Tunisia: an empirical analysis of the environmental Kuznets curve. Energy Policy 2010;38:1150-6.

[40] Kolb A, Wacker M. Calculation of energy consumption and pollutant emissions on freight transport routes. The Science of the Total Environment 1995:169.

[41] Leonardi J, Baumgartner $\mathrm{M}$. $\mathrm{CO}_{2}$ reduction and efficiency in road freight transport-measures, baseline and potential, presentation at the $23 \mathrm{rd}$ meeting of the international energy workshop 2004. Paris; 22-24 June 2004.

[42] Schipper L, Scholl L, Price L. Energy use and carbon emissions from freight in 10 industrialized countries: an analysis of trends from 1973 to 1992. Transportation Research 1997;2 D:57-76.

[43] Akinboade O, Ziramba E, Kumo W. The demand for gasoline in South Africa: an empirical analysis using co-integration techniques. Energy Economics 2008;30:3222-9.

[44] Sorrell S, Lehtonen M, Stapleton L, Pujol J, Champion T. Decomposing road freight energy use in the United Kingdom. Energy Policy 2009;37:3115-29.

[45] Lu IJ, Lewis C, Lin SJ. The forecast for motor vehicle, energy demand and emission from Taiwan's road transportation sector. Energy Policy 2009;37:2952-61.

[46] Yaobin L. Exploring the relationship between urbanization and energy consumption in China using ARDL (autoregressive distributed lag) and FDM (factor decomposition model). Energy 2009;34:1846-54.

[47] Pongthanaisawan J, Sorapipatana C. Relationship between level of economic development and motorcycle and car ownerships and their impacts and greenhouse gaz emission in Thailand. Renewable and Sustainable Energy Reviews 2010;14:2966-75.

[48] Yan X, Crookes RJ. Energy demand and emissions from road transportation vehicles in China. Progress in Energy and Combustion Science 2010;36: 651-76.
[49] Rudra PP. Transport infrastructure, energy consumption and economic growth triangle in India: cointegration and causality analysis. Journal of Sustainable Development 2010;3:167-73.

[50] Niovi K, Daniel JG, Robert BN. Estimating the effect of urban density on fuel demand. Energy Economics 2010;32:86-92.

[51] Marshall L, Joseph LS, Pablo D, Kimberly AG. The effect of residential location on vehicle miles of travel, energy consumption and greenhouse gas emissions: Chicago case study. Transportation Research Part D 2011;16:1-9.

[52] Reinhard M, Yasin S. Impacts of urbanization on urban structures and energy demand: what can we learn for urban energy planning and urbanization management? Sustainable Cities and Society 2011;1:45-53.

[53] Panayotou T. Demystifying the environmental Kuznets curve: turning a black box into a policy tool. Environment and Development Economics 1997;42: 265-84.

[54] De Bruyn S, Vanden Bergh J, Opschoor J. Economic growth and emissions: reconsidering the empirical basis of environmental Kuznets curves. Ecological Economics 1998;25:161-75.

[55] Roca J, Padilla E, Farre M, Galletto V. Economic growth and atmospheric pollution in Spain: discussing the environmental Kuznets curve hypothesis. Ecological Economics 2001;39:85-99.

[56] Hung MF, Shaw D. Economic growth and the environmental Kuznets cure in Taiwan: a simultaneity model analysis. Department of Economics: Mimeo National Cheng-Chi University; 2002.

[57] Ghosh S. Examining carbon emissions economic growth nexus for India: a multivariate cointegration approach. Energy Policy 2010;38:3008-14.

[58] Shahbaz M, Hooi Lean H, Shabbir MS. Environmental Kuznets curve hypothesis in Pakistan: cointegration and Granger causality. Renewable and Sustainable Energy Reviews 2012;16:2947-53.

[59] Shahbaz M, Mutascu M, Azim P. Environmental Kuznets curve in Romania and the role of energy consumption. Renewable and Sustainable Energy Reviews 2013;18:165-73.

[60] Cole MA, Rayner AJ, Bates JM. The environmental Kuznets curve: an empirical analysis. Environment and Development Economics 1997;2(4):401-16.

[61] Hilton FGH, Levinson AM. Factoring the environmental Kuznets curve: evidence from automotive lead emissions. Journal of Environmental Economics and Management 1998;35:126-41.

[62] Tanishita M, Miyoshi H. Safety and fuel economy of passenger cars. ITEC working paper series 07-03; 2007.

[63] Kahn MEA. Household level environmental Kuznets curve. Economic Letters 1998;59:269-73.

[64] NAEC. National Agency for Energy Conservation; 2011

[65] NAEC. National Agency for Energy Conservation; 2009.

[66] Newman P, Kenworthy JR. The transport energy trade off: fuel-efficient traffic versus fuel-efficient cities. Transportation Research part A 1988;3:163-74.

[67] NAEC. National Agency for Energy Conservation; 2002.

[68] NIC. National Institute of Statistics; 2012.

[69] Chang T, Fang W, Wen LF. Energy consumption, employment, output and temporal causality: evidence from Taiwan based on cointegration and errorcorrection modelling techniques. Applied Economics 2001;33:1045-56.

[70] Stock JH, Watson MW. Interpreting the evidence on money-income causality. Journal of Econometrics 1989;40:161-82.

[71] Nelson CR, Plosser CI. Trends and random walks in macroeconomic time series. Journal of Monetary Economics 1982:129-62.

[72] Johansen S, Juselius K. Maximum likelihood estimation and inference on cointegration with applications to the demand for money. Oxford Bulletin of Economics and Statistics 1990;52:169-210.

[73] Asafu-Adjaye J. The relationship between energy consumption, energy prices and economic growth: time series evidence from Asia developing countries. Energy Economics 2000;22:615-25.

[74] Yu ESH, Jin JC. Cointegration tests of energy consumption, income and employment. Resources Energy 1992;14:259-66.

[75] Grossman GM, Krueger AB. Economic growth and the environment. Quarterly Journal of Economics 1994;110:353-77.

[76] Harbaugh W, Levinson A, Wilson D. Re-examining the empirical evidence for an environmental Kuznets curve. The Review of Economics and Statistics 2002;84:541-51.

[77] Seldon T, Song D. Environmental quality and development: is there a Kuznets curve for air pollution emissions. Journal of Environmental Economics and Management 1994;27:147-62.

[78] Holtz-Eakin D, Selden T. Stoking the fires? $\mathrm{CO}_{2}$ emissions and economic growth Journal of Public Economics 1995;57:85-101.

[79] Koop G, Tole L. Is there an environmental Kuznets curve for deforestation? Journal of Development Economics 1999:58:231-44.

[80] Stern DI, Common MS. Is there an environmental Kuznets curve for sulfur? Journal of Environmental Economics and Management 2001;41:162-78.

[81] Masih AMM, Masih R. Energy consumption, real income and temporal causality: results from a multi-country study based on cointegration and error-correction modeling techniques. Energy Economics 1996;18:165-83.

[82] Al-Hinti I, Al-Ghandoor A, Akash B, Abu-Nada E. Energy savings and $\mathrm{CO}_{2}$ mitigations through restructuring Jordan's transportation sector: the diesel passenger cars scenario. Energy Policy 2007;35:5003-11. 